\title{
Prevalence of bovine mastitis in smallholder lactating dairy farms in Hawassa, SNNPR, Ethiopia
}

\author{
Mulugeta Sosango ${ }^{1}$, Amanuel Ashebo ${ }^{2}$ and Demelash Kalo ${ }^{3 *}$ \\ ${ }^{1}$ School of Veterinary Medicine, Hawassa University, P. O. Box 05, Hawassa, Ethiopia. \\ ${ }^{2}$ Hedero Tunto Zuria Woreda Livestock and Fishery Resource Office, Kembeta Tembaro Zone, \\ SNNPR, Ethiopia. \\ ${ }^{3}$ Gerese Woreda Livestock and Fishery Office Resource, Gamo zone, SNNPR, Ethiopia. \\ *Corresponding author. Email: demelashkalo@gmail.com
}

Copyright (C) 2020 Sosango et al. This article remains permanently open access under the terms of the Creative Commons Attribution License 4.0, which permits unrestricted use, distribution, and reproduction in any medium, provided the original work is properly cited.

Received 29th July, 2020; Accepted 20th October, 2020

\begin{abstract}
A cross sectional study was conducted between November 2015 and February 2016 in Hawassa town, SNNPR, Ethiopia to determine the overall mastitis prevalence and identify the role of some selected risk factors in 183 randomly selected small holder lactating dairy cows of 53 high grade Holstein Friesian, 113 Holstein indigenous zebu cross and 17 indigenous zebu breeds. The prevalence of clinical mastitis was determined through examination of abnormalities of milk, udder or cow. The prevalence of subclinical mastitis determined by using indicator paper test. From total 183 lactating dairy cows examined for bovine mastitis $9(4.9 \%)$ had clinical mastitis, while $56(30.6 \%)$ subclinical mastitis. Out of $9(4.9 \%)$ clinical mastitis, 9.43 and $3.53 \%$ occurred in high grade Holstein and Holstein indigenous zebu, respectively, but indigenous zebu breed was found not affected. Subclinical mastitis at cow level based on indicator paper test was significantly high (32.07\%) in Holstein, (30.9\%) in cross breed and (23.5\%) in indigenous zebu ( $p<0.05)$. Quarter level subclinical mastitis prevalence based on indicator paper test was $32.07,30.2 \%$ and $23.5 \%$ in Holstein, cross breed and indigenous zebu, respectively. From the potential risk factors considered, breed $\left(X^{2}=17.3, p<0.05\right)$, presence of teat lesion and tick infestation $\left(X^{2}=7.73, p<0.05\right)$, stage of lactation $\left(X^{2}=13.8, p<0.05\right)$, and parity number $\left(X^{2}=19.4, p<0.05\right)$ had significant effect on the prevalence of subclinical mastitis. Considering the possible significant economic losses that could be incurred by both clinical and subclinical mastitis, attention should be paid for further detailed investigation and control measures.
\end{abstract}

Keywords: Bovine mastitis, prevalence, clinical, mastitis, risk factor, smallholder.

\section{INTRODUCTION}

As human population pressure is increasing, famine and competition for resource combined with severe recurrent droughts and declining per capita production of food in Africa, there is an urgent need to develop previously marginalized resources, through appropriate livestock production system of which dairy cattle production is the most suitable one in the region. Dairy production is a biologically efficient system that converts large quantities of roughage, the most abundant feed in the tropics, to milk, the most nutritious food known to man (ILRI, 1998). Where there is access to a market, dairying is preferred to meat production since it makes more efficient use of feed resources and provides a regular income to the producer. It is also more labor intensive and supports substantial employment in production, processing and marketing. The challenge represented by the expanding demand for milk and dairy products in tropical countries is great, and the resultant opportunities for smallholders are large (Walshe et al., 1991).

Ethiopia has the largest livestock population in Africa with an estimated 80 million tropical livestock units (TLU) including 31 million cattle, 42 million sheep and goats, 7 
million equines (CTA, 1997; Tegene et al., 1999). Livestock sector has been contributing considerable portion to the economy of the country, and still promising to rally round the economic development of the country (Nejash, 2016). In Ethiopia, south nation, nationalities, people's regional (SNNPR) state has got significant amount of livestock population compared to other regions that contribute to the economic growth. With the zonal level in the region; Sidama zone of SNNPR regional state are known in livestock population having 1,573,318 cattle, 183,462 goats, 221,505 sheep, 49,150 horses, 48, asses and $1,196,506$ poultry (CSA, 2003).

Even though having the largest livestock population in Africa, the contribution to the economy of the country is still the low due to disease as a major obstacle (Nejash, 2016). There are several diseases which affect the wellbeing of livestock population among which mastitis is the commonest and most costly, causing loss in milk yield, and adding to treatment cost and the disease is considered as the most complex disease because of multifactorial causation (Harmon, 1994). Despite many years of research, mastitis remains the most economically damaging disease for the dairy industry worldwide and it has also public health importance by serving as a vehicle in the spread of diseases like tuberculosis, staphylococcal food poisoning and brucellosis (Radostits et al., 2007). Food poising is produced when milk, milk products, or food prepared with milk products containing strains of bacteria associated with food poisoning is stored at temperatures that enhance rapid multiplication of the organisms. Some Staphylococci that cause mastitis may also produce the entero-toxin (Hirsh and Zee, 1999).

The economic losses of dairy industry due to mastitis remain the major constraint of the industry all over the world. According to the study carried out in England and Wales from 1989 to 1992, the average cost of a case of mastitis due to antibiotics used, milk discarded, reduction in quality and quantity of milk produced by a cow was estimated 60 pounds sterling for each case (Blowey, 1990) and the economic loss due to both clinical and subclinical mastitis per lactation in Ethiopia is 270 ETB (Mungube et al., 2005). Based on the earlier research works, on the average, the affected quarter suffers a $30 \%$ reduction in productivity and affected cow a $15 \%$ loss in productivity (Blood and Radostits, 1989).

According to the report of FAO (2003), the total annual national milk production in Ethiopia ranges from 797,900 to $1,197,500$ metric tons of raw milk. Out of total national milk production, between 85 and $89 \%$ is contributed from cattle. However, this amount is far below the national demand for milk and milk products in the country. Many reasons could be ascribed for the low annual national milk yield among which mastitis is one of the most important factors. A number of reports indicated that mastitis is a serious problem in the dairy industry of Ethiopia. Nesru (1999) reported mastitis prevalence rates of 85.8 and $81.2 \%$ using California Mastitis (CMT) and Somatic Cell
Count (SCC) respectively. According to the same report, out of the CMT positive animals, $37.2 \%$ did harbor a causal agent for mastitis. Biru (1989) reported a combined mastitis prevalence of $67.4 \%$ at cow level while Bishi (1998) reported a subclinical mastitis prevalence of 35.5 and $34.3 \%$ for small and large scale farms, respectively.

Mastitis disease has received little attention in Ethiopia; especially the subclinical form. Efforts have only been concentrated on the treatment of clinical cases (Nesru et al., 1997). Bovine mastitis is the most important disease of dairy cows. Owing to the heavy financial implications involved and the inevitable existence of latent infections, mastitis is obviously an important factor that limits dairy production.

Very limited research works have been done concerning the status of bovine mastitis in Hawassa city, SNNPR unlike that of other areas of the country. The study area is one of the most known dairy areas in the country, where smallholder dairy production is practiced. Therefore, this study was designed to estimate the prevalence of bovine mastitis in smallholder lactating dairy cows in Hawassa, SNNPR, Ethiopia.

\section{MATERIALS AND METHODS}

\section{Study area}

The study was carried out in Hawassa town, SNNPR Regional State, from November, 2015 to February, 2016. Geographically, Hawassa is situated between latitude $4^{\circ} 27^{\prime}$ and $8^{\circ} 80^{\prime} \mathrm{N}$ and longitude $34^{\circ} 25^{\prime}$ and $39^{\circ} \mathrm{E}$. The city's estimated human population is 150,000 with an area of 50 $\mathrm{km}^{2}$ and the altitude range from 1500 to 2000 meters above at sea level. The mean annual rainfall of the city is 800 to $1000 \mathrm{~mm}^{3}$ and the daily mean maximum and minimum temperatures are 25 and $20.1^{\circ} \mathrm{C}$ respectively. The minimum and maximum annual temperatures are 10 and $25^{\circ} \mathrm{C}$, respectively (CSA, 2003).

\section{The study animal}

The study animals that had been sampled were lactating small holder dairy cows of different herds with different calving history and management conditions. The study animals in this study were high grade Holstein Fresian, predominantly Holstein-indigenous zebu crossbreeds and indigenous local zebu lactating cows in smallholder farms. The average herd size was 5.5 and the maximum was 23 lactating cows SOS dairy farm. The total cattle population of Sidama zone is estimated to be $1,573,318$ cattle (CSA, 2003). Regarding the management system: only two farms was an intensive management but the rest were under a semi-intensive and extensive management type. Local zebu lactating cows were kept in a traditional-extensive husbandry system and their feeds were entirely dependent 
on the natural pasture and agricultural by-products. A total of 183 smallholder lactating cows were examined from 25 smallholder dairy farms in Hawassa city, SNNPR Regional state.

\section{Methods}

A cross sectional study was used to determine the prevalence of bovine mastitis. Both clinical and subclinical mastitis prevalence were determined at cow and quarters level based on clinical examination for clinical mastitis and indicator paper test for subclinical mastitis. Sample size was determined according to Thrusfield (2005) at $95 \% \mathrm{Cl}$, $5 \%$ precision and with expected prevalence of $38 \%$ (Demelash et al.,2005). A total of 183 smallholder lactating dairy cows: 17 indigenous local zebu, 113 Holstein Friesian-indigenous zebu cross and 53 high grade Holstein, relatively under the same management were included in the study.

\section{Clinical examination for clinical mastitis}

To determine the prevalence of clinical mastitis, udder was examined for visible abnormalities symmetry, size, consistency, presence of lesions and ticks. Milk was examined for any change using strip cup in color, consistency and for grossly visible changes. Clinical mastitis was recognized by some pathology in udder, which is manifested by swelling, pain, redness and heat in case of acute mastitis. Whereas, hardening of the udder, blockage of teats, atrophy or fibrosis and abscess formation were manifested in chronic mastitis. Acute mastitis was also recognized by changing in milk color, presence of flakes and clots.

\section{Indicator paper test}

To determine prevalence of subclinical mastitis, the milk samples were screened using indicator paper. It was carried out by adding a drop of milk sample to the test paper and observing the color change of the paper. If yellow color of the paper is not changed and remained as it is or showed slight change, such sample was considered as negative. A change of color from yellow to green was recorded as positive.

\section{Risk factors}

Semi structured questionnaire was compiled to evaluate the effect of selected potential risk factors on the occurrence of mastitis. Risk factors considered at cow attributes were breed (high grade Holstein -Friesian, Holstein indigenous zebu cross breed and indigenous zebu breeds), parity, and stage of lactation (early, middle and late) and the presence/absence of tick or lesion or udder injury on udder skin or teat and previous mastitis history. The stage of lactation was categorized into three levels as 1-120 days post partum (early lactation), 121-240 days (middle lactation) and days greater than 240 (late lactation) and similarly parity was categorized as $\leq 3$ calves birth and 4-7 calves.

\section{Data analysis}

Prevalence of bovine mastitis related to specific risk factors was determined as the proportion of affected cows out of the total examined (Thrusfield, 2005). Effects of specific variables including breed, age, parity, tick infestation, udder injury and or teat injuries, stage of lactation and previous history of mastitis were investigated using chi-square and these were calculated to assess the risk levels of categories under each risk factor and analyzed using Stata 7 statistical software package. In all chi-square test application, probability of $p<0.05$ was considered statistically significant.

\section{RESULTS}

In this study, a total of 113 Holstein Friesian $\mathrm{x}$ indigenous zebu cross breed, 53 high grade Holstein Friesian and 17 indigenous zebu cows were investigated in 25 smallholder dairy farms. Each farm holds a minimum of 6 and a maximum of 23 lactating cows. Both clinical and subclinical mastitis prevalence was determined crosssectional at cow and quarter level based on clinical examination for clinical mastitis and indicator paper test for subclinical mastitis. Invariably, all the smallholder dairy farms under the study practiced hand-milking. Prevalence of bovine mastitis varied significantly among the different risk factors associated with the occurrence of mastitis under this study and the results on the prevalence and risk assessments are given independently.

\section{Prevalence of clinical and subclinical mastitis}

Among 183 lactating cows examined in small holder dairy farms in Hawassa town, SNNPR state for bovine mastitis $9(4.9 \%)$ had clinical mastitis, while $56(30.6 \%)$ were subclinical mastitis cases. Out of $4.9 \%$ clinical mastitis, $9.43 \%$ occurred in high grade Holstein and $3.53 \%$ Holstein indigenous zebus cross and none clinical mastitis was observed in indigenous zebu breeds. Based on indicator paper test, subclinical mastitis prevalence was $30.6 \%$ at cow level (Table 1).

At quarter level, out of 732 quarters belonging to 56 cows, $104(14.2 \%)$ were found to be affected by subclinical mastitis. The occurrence of subclinical mastitis by quarter 
Table 1. Prevalence of clinical and subclinical mastitis at cow and quarter level in small holder dairy cows.

\begin{tabular}{lcccccc}
\hline \multirow{2}{*}{ Observed level } & \multicolumn{3}{c}{ Clinical mastitis } & \multicolumn{3}{c}{ Subclinical mastitis } \\
\cline { 2 - 7 } & No. examined & Positive case & $\%$ & No. examined & Positive case & $\%$ \\
\hline Cow level & 183 & 9 & $4.9 \%$ & 183 & 56 & $30.6 \%$ \\
Quarter level & 732 & 20 & $2.73 \%$ & 732 & 104 & $14.2 \%$ \\
\hline
\end{tabular}

Table 2. Prevalence and distribution of udder infections across the four quarter in dairy cows.

\begin{tabular}{lcccc}
\hline Parameters & \multicolumn{2}{c}{ Clinical mastitis } & \multicolumn{2}{c}{ Subclinical mastitis } \\
\hline No. of quarters examined & 732 & Prevalence & 732 & Prevalence \\
No. of quarters affected & 20 & $2.7 \%$ & 104 & $14.2 \%$ \\
Front left & 3 & $15 \%$ & 24 & $23.07 \%$ \\
Front right & 6 & $30 \%$ & 27 & $25.9 \%$ \\
Hind left & 5 & $25 \%$ & 27 & $25.9 \%$ \\
Hind right & 6 & $30 \%$ & 26 & $25 \%$ \\
\hline
\end{tabular}

Table 3. Prevalence of subclinical mastitis with associated risk factors.

\begin{tabular}{|c|c|c|c|c|c|c|c|c|c|c|c|c|}
\hline \multirow{2}{*}{ Cows } & \multicolumn{3}{|c|}{ Breeds } & \multicolumn{3}{|c|}{ Stage of lactation } & \multicolumn{2}{|c|}{ Parity no. } & \multicolumn{2}{|c|}{$\begin{array}{l}\text { Lesions/udder } \\
\text { injuries }\end{array}$} & \multicolumn{2}{|c|}{$\begin{array}{c}\text { Ticks } \\
\text { infestation }\end{array}$} \\
\hline & aHF & bHIZ & cZ & Early & Mid & Late & $\begin{array}{c}\text { Calves } \\
(1-3)\end{array}$ & $\begin{array}{c}\text { Calves } \\
(4-7)\end{array}$ & + & - & + & - \\
\hline Exan & 53 & 1 & 17 & 66 & 67 & 50 & 142 & 41 & 9 & 17 & 10 & 173 \\
\hline Infected & 17 & 35 & 4 & 14 & 17 & 25 & 32 & 24 & 7 & 49 & 7 & 49 \\
\hline Prevalence (\%) & 32.07 & 30.9 & 23.5 & 21.2 & 25.3 & 50 & 22.5 & 58.5 & 77.7 & 27.8 & 70 & 27.8 \\
\hline
\end{tabular}

${ }^{\mathrm{a}} \mathrm{HF}=$ Holstein Friesian, ${ }^{\mathrm{b}} \mathrm{HIZ}=$ Holstein indigenous zebu cross, ${ }^{c} \mathrm{Z}=$ indigenous zebu, $+=$ present, $-=$ absent.

Table 4. Risk factors of bovine subclinical mastitis.

\begin{tabular}{lcc}
\hline Variables & $\mathbf{X}^{2}$ & P-value \\
\hline Breed & 17.3 & 0.05 \\
Stage of lactation & 13.8 & 0.001 \\
Parity & 19.42 & 0.01 \\
Presence of tick and/or udder injury & 7.73 & 0.005 \\
\hline
\end{tabular}

location was $24(23.07 \%), 27(25.9 \%), 26(25 \%)$ and 27 $(25.9 \%)$ in the left front (LF), right front (RF), right hind $(\mathrm{RH})$ and left hind (LH) respectively (Table 2). The difference in prevalence between the quarters was not statistically significant $\left(X^{2}=19.4, p>0.05\right)$. The quarter level subclinical mastitis prevalence by breed was found to be $32.07,30.9$ and $23.52 \%$ in high grade Holstein Friesian, Holstein indigenous zebu cross breed and indigenous zebu breeds respectively. Both at cow and quarter level, prevalence is high in high grade Holstein Friesian compared to Holstein-indigenous zebu cross and indigenous local breeds.

\section{Risk factors associated with sub-clinical mastitis}

The prevalence of subclinical mastitis was significantly higher in high grade Holstein-Friesian (32.07\%) than
Holstein indigenous zebu cross breed (30.9\%) and indigenous zebu $(23.52 \%)\left(X^{2}=17.3, p<0.05\right)$, in cows with a lesion and/or tick infestation on the skin of teat and/or udder than in cows without this factors $\left(X^{2}=7.73, p<0.05\right)$, cows with high number of calves (4-7) $(58.5 \%)$ than those of cows having less (1-3) calves (22.5\%) ( $X^{2}=19.4$, $\mathrm{p}<0.05)$, in late lactation $(50 \%)$ than mid lactation $(23.37 \%)$ and early lactation $(21.2 \%)\left(X^{2}=13.8, p<0.05\right)$. In the present study, selected potential risk factors breed $(p<0.05)$ have statistically significant effect (Table 4$)$, but others selected risk factors have no significant effects in the prevalence of sub-clinical mastitis $(p<0.05)$.

\section{DISCUSSION}

This study has given a due attention to determine the prevalence and its risk factor assessment for bovine 
mastitis. The mean prevalence of mastitis of $40 \%$ in cows and $19 \%$ in quarters was in line with the recent assertion by Radostits et al. (2000) that, in most countries and irrespective of the cause, the prevalence rate of mastitis is about $50 \%$ in cows and $25 \%$ in quarter. The overall prevalence of clinical mastitis in this study was $4.9 \%$ which is comparable to the report done in different dairy farms: $3.54 \%$ in Diredawa Autonomus and East Hararge Administration Region (Daresema, 1991); 4.4\% in and around Gondar (Tewedros, 2007); 6.55\% in and around Mekelle (Wudu, 1999); $7 \%$ in three states dairy farms around Addis Ababa, (Yirgalem, 1987); 3.9\% in Baire Dare (Almaw et al., 2008); and 6.6\% in the central high lands off Ethiopia (Mungube et al., 2005) while it was lower in the wolaita sodo, southern Ethiopia (15.1\%) (Biffa, 1994); $16.11 \%$ in and around Sebete in Ethiopia (Hunerra et al., 2005); $19.8 \%$ in dairy farms in Daire-Dawa Administrative Council and Eastern Hararghe zone (Birhanu, 1997); 21\% in two major state owned dairy farms at Rapi and Deber Zeit, Ethiopia (Workineh et al., 2002) but it was a far lower $(37 \%)$ in the research finding in selected area of southern Ethiopia (Dego and Tareke, 2003).

Subclinical mastitis was high in all breeds compared to clinical mastitis. The prevalence of subclinical mastitis at cow level based on indicator paper test in the present study $(30.6 \%)$ was comparable to the report done in different dairy farms: $34.4 \%$ in Bair Dar (Almaw et al., 2008); 34.3\% (Bishi, 1998); 34.6\% (Abaineh and Sintayehu, 2001); 45.4\% (Sori et al., 2005) in commercial farms in Ethiopia. But the present finding is by far lower than the reports of Dego and Tareke (2003) in local, Friesian and Jersey cows in Ethiopia (63\%); Machang and Muyungi (1998) in Tanzania. Mastitis is a complex disease and the difference in results could be due to variations in herd size, management practices, proportion of exotic gene inheritance, agro-climates and other risk factors might have contributions to the observed differences in prevalence rates of mastitis among the finding of the various workers.

The significant difference between the high grade Holstein-Friesain, Holstein indigenous zebu cross breed and indigenous zebu may be associated with their high yield. Radostits et al. (2007) stated that high yielding cows are more susceptible to mastitis than low-yielding ones. This may be due to the ease with which injuries are sustained in large udders, so that foci for the entrance of pathogens are created, and stress associated with a high milk yield may upset the defense system of the animal (Radostits et al., 2000). On the other hand, this difference between breeds may be due to other uncontrolled factors, such as management, rather than to a true breed difference, since cows in this study were not all under the matching conditions. Further study is required to evaluate the breed difference.

The significant effect of stage of lactation on prevalence of subclinical mastitis in this study was $(21.2 \%),(25.37 \%)$ and $(50.0 \%)$ in early, mid and late lactation respectively, as reported also by Nesru (1999), Mungube et al. (2004), Dego and Tareke (2003) and Biffa et al. (2005) in Ethiopia. The former two authors reported high prevalence of subclinical mastitis foe cows in mid and late stage of lactation as it is the case in this finding, while the late two reported higher prevalence in early stage of lactation. The variations in the effect of stage of lactation between the different studies could be related probably to the disparities in age, parity and breed of the sampled animals.

Animals with skin lesion on their teats and/or udder had a high prevalence of mastitis, possibly because of colonization of the lesion by pathogens. Mulei (1999) found, in the Kiambu district of Kenya, that mammary gland quarters with teat lesions were 7.2 times more likely to have a positive CMT and 5.6 times more likely to have bacterial organisms isolated from them than those without any teat lesions. In this study, the prevalence of subclinical mastitis was significantly higher in cows with teat lesions. Similar findings were reported by Sori et al. (2005), Dego and Tareke (2003) and Biffa et al. (2005) where the prevalence of subclinical mastitis was significantly higher in cows with teat lesions.

Parity was found a significant influence on the prevalence of subclinical mastitis. Cows with 4 to 7 calves were more prevalence $(58.5 \%)$ than those of cows having 1 to 3 calves $(22.5 \%)$. In this study, the risk of subclinical mastitis increases with increasing parity number which is agreement with finding of Busato et al. (2000) who found that the risks of clinical and subclinical mastitis increase significantly with advancing age of the cow, which approximates to the parity number.

In Ethiopia, the subclinical form of mastitis received little attention and the efforts have been concentrated on the treatment of clinical case (Nesru et al., 1997). According to Mungube et al. (2005), losses associated with subclinical mastitis (SCM) in cross breed dairy cows in the central high land of Ethiopia was found to be US\$38 for each cow per lactation. Usually, Ethiopia farmers, especially smallholders are not well informed about the invisible loss from subclinical mastitis (Nesru, 1999) and were also true in Tanzanian farmers (Kivaria et al., 2004).

\section{Conclusion and Recommendations}

Bovine mastitis is the important disease which affects the profitability of the dairy industry, not only the dairy farm business but also the economy of the country would also be affected, just by increasing the cost in different forms as it occurred once. Most research works showed that on the average, the affected quarter suffers a 30\% reduction in productivity and affected cow a $15 \%$ loss of its production. Taking into account these figures, the overall cow level $30.6 \%$ and quarter level $14.2 \%$ prevalence of mastitis in the present study signify the effect of mastitis in Hawassa dairy farming. In this study, a significant number of mastitis were subclinical $(30.6 \%)$ compared to clinical 
cases (4.9\%). The occurrence of mastitis was found to be associated with breed, parity, stage of lactation and presence of teat and/or udder lesions. Therefore, based on the above conclusions the following recommendations are forwarded:

1. It is essential that smallholder dairy owners in the study area should be advised to avoid teat injury, monitor the udder health status regularly and implement control strategies as required.

2. Awareness should also be created among smallholder farmers about the economic impact and benefits in controlling mastitis.

3. Adequate housing with proper sanitation and regular screening for early detection and treatment, follow up of chronic cases, culling of older cows with repeated attacks should be presented and practiced by the owners.

4. Farmers need to be advised to avoid the frequent use of one type of antimicrobial for long period and the need to consult animal health professionals for prescription and administration of drugs.

5. Dry cow therapeutic should be implemented by veterinary professionals.

\section{CONFLICT OF INTEREST}

The authors declare that they have no conflict of interest.

\section{REFERENCE}

Abaineh, D., \& Sintayehu, A. (2001). Treatment trial of subclinical mastitis with the herb Persicaria senegalense (Polygonaceae). Tropical Animal Health and Production, 33(6), 511-519.

Almaw, G., Zerihun, A., \& Asfaw, Y. (2008). Bovine mastitis and its association with selected risk factors in smallholder dairy farms in and around Bahir Dar, Ethiopia. Tropical Animal Health and Production, 40(6), 427-432.

Biffa, D. (1994). A study on the prevalence of bovine mastitis in indigenous zebu cattle and Jersey breed in Wollaita Sodo, Characterization and in vitro drug sensitivity of isolates. DVM Thesis, Faculty of Veterinary Medicine, Addis Ababa University, Debrezeit, Ethiopia.

Biffa, D., Debela, E., \& Beyene, F. (2005). Prevalence and risk factors of mastitis in lactating dairy cows in Southern Ethiopia. International Journal of Applied Research in Veterinary Medicine, 3(3), 189-198.

Birhanu, S. (1997). Bovine mastitis in dairy farm in Dire Dawa Administrative council and western Harareghe Zone. Prevalence, isolation and invitro anti-microbial susceptibility study. DVM thesis, Addis Ababa University, faculty of Veterinary medicine, Ethiopia.

Biru, G. (1989). Major Bacteria Causing Bovine Mastitis and their Sensitivity to Common antibiotics. Ethiopian Journal of Agricultural Sciences, 11, 47-54.

Bishi, A. B. (1998). Cross sectional and longitudinal prospective study of bovine clinical, subclinical mastitis in per-urban and urban dairy production system in Addis Ababa Region. Msc. Thesis, Addis Ababa University, Faculty of Veterinary Medicine, Debre-Zeit, Ethiopia.

Blood, D. C., \& Radostitis, O. M. (1989). Mastitis. In: Veterinary Medicine. A Text Book of the disease of cattle, sheep, goat and horses, 7th edition. London: Bailliere Tindal, Pp. 501-599.

Blowey, R. W. (1990). Mastitis and conditions of the udder. In: A veterinary book for dairy farmers. 22nd edition. Pp. 181-229.

Busato, A., Trachsel, P., Schällibaum, M., \& Blum, J. W. (2000). Udder health and risk factors for subclinical mastitis in organic dairy farms in Switzerland. Preventive Veterinary Medicine, 44(3-4), 205-220.

CSA (2003). Ethiopia agricultural sample enumeration results for south region.

CTA (1997). Technical center for agricultural and rural cooperation (CTA) livestock development policies in eastern and Southern Africa. Proceeding. OAU IBAR, and ministry of agriculture and cooperatives, Swaziland. Pp. 216-220.

Daresema, G. (1991). A survey of bovine mastitis in different dairy farms of Dire-dawa Autonomous and east Harareghe Administrative Region, DVM thesis, Addis Ababa University, Faculty of veterinary medicine, Ethiopia.

Dego, O. K., \& Tareke, F. (2003). Bovine mastitis in selected areas of southern Ethiopia. Tropical animal health and production, 35(3), 197-205.

Demelash, B., Debela, E., \& Beyene, F. (2005) Prevalence and risk factors of mastitis in lactating dairy cows in Southern Ethiopia. International Journal of Applied Research in Veterinary Medicine, 3(3), 189-198.

FAO (2003). Livestock sector brief. Livestock information, sector analysis and policy branch April 2003, Pp. 1-15.

Harmon, R. J. (1994). Symposium-mastitis and genetic evaluation for somatic-cell count-physiology of mastitis and factors affecting somatic-cell counts. Journal of Dairy Science, 77(7), 2103-2112.

Hirsh, D. C., \& Zee, Y. C. (1999). Veterinary microbiology, 1st edition. Black Well Science.

Hunerra, B., Etana, D., Ademe, Z., \& Sintayehu, A. (2005). Dairy cattle mastitis in and around Sebeta, Ethiopia. International Journal Applied Research Veterinary Medicine, 3(4), 15251530.

International Livestock Research Institute (ILRI) (1998). Dairy production systems in the tropics: A review. Working Document No. 5.

Kivaria, F. M., Noordhuizen, J. P. T. M., \& Kapaga, A. M. (2004). Risk indicators associated with subclinical mastitis in smallholder dairy cows in Tanzania. Tropical Animal Health and Production, 36(6), 581-592.

Machang, U. R. S., \& Muyungi, L. (1988). The occurrence of streptococci mastitis in dairy farms in Morogoro area, Tanzania. Bulletin of Animal Health and Production in Africa, 36, 190-193.

Mulei, C. M. (1999). Teat lesions and their relationship to intramammary infections on small-scale dairy farms in Kiambu district in Kenya: research communication. Journal of the South African Veterinary Association, 70(4), 156-157.

Mungube, E. O., Tenhagen, B. A., Regassa, F., Kyule, M. N., Shiferaw, Y., Kassa, T., \& Baumann, M. P. O. (2005). Reduced milk production in udder quarters with subclinical mastitis and associated economic losses in crossbred dairy cows in Ethiopia. Tropical Animal Health and Production, 37(6), 503512.

Nejash, A. A. (2016). Bovine Babesiosis and its current status in Ethiopia: A review. Journal of Medicine, Physiology and 
Biophysics, 23, 15-23.

Nesru, H. (1999). A cross-sectional and longitudinal study of bovine mastitis in urban and peri-urban dairy system in the Addis Ababa Region. Msc. Thesis. Free University of Berlin and Addis Ababa University, Ethiopia.

Nesru, H., Yohualashet, T., \& Tilahun, G. (1997). Prevalence of mastitis in different local and exotic breeds of milking cows. Proceedings of Institute of Agricultural Research, 4, 256-262.

Radostits, O. M., Blood, D. C., \& Gay, C. C. (1994). Mastitis. In: veterinary medicine: Text book of the disease of cattle, sheep,goat and horses, 8th edition. London: Baillier Tindall, Pp. 563-614.

Radostits, O. M., Blood, D. C., Gay, C. C., \& Hinchliff, K. W. (2000). Mastitis veterinary medicine. A text book of the disease of cattle, sheep, pigs, goats and horses. 9th edition. London: W.B. Saunders, 603-700.

Radostits, O. M., Gay, C. C., Hincheliff, K. W., \& Constable, P. D. (2007). Veterinary Medicine. A Textbook of the disease of cattle, sheep, pigs and goats, 10th edition. London: Ballieer, Tindall.

Sargeant, J. M., Scott, H. M., Leslie, K. E., Ireland, M. J., \& Bashiri, A. (1998). Clinical mastitis in dairy cattle in Ontario: frequency of occurrence and bacteriological isolates. The Canadian Veterinary Journal, 39(1), 33-38.

Sori, H., Zerihun, A., \& Abdicho, S. (2005). Dairy cattle mastitis in and around Sebeta, Ethiopia. Journal of Applied Research in Veterinary Medicine, 3(4), 332-338.
Tegene, T., Alemayehu, A., \& Ayele, G. M. (1999). Cross-breed livestock trade and food security in southern and south eastern Ethiopia. Organization for social science research in Eastern and Southern Africa (OSSREA) development research report services. Commercial printing Enterprise Addis Ababa, Ethiopia. $1 ; 1$.

Tewedros, A. (2007). Prevalence and economic significance of bovine mastitis in and around Gondar. DVM thesis Mekelle University Faculty of veterinary medicine, Ethiopia.

Thrusfield, M. (2005). Veterinary Epidmiology. 3rd edition. Singapore: Black well science.

Walshe, M. T., Grindle, T., Nell, A., \& Baschaman, M. (1991). Dairy development in Sub Saharan Africa: A study of issues and options, world bank technical paper, 135, Africa Technical Development series, Washington D.C., The World Bank.

Workineh, S., Bayleyegn, M., Mekonnen, H., \& Potgieter, L. N. D. (2002). Prevalence and aetiology of mastitis in cows from two major Ethiopian dairies. Tropical Animal Health and Production, 34(1), 19-25.

Wudu, T., (1999). Study on bovine mastitis in and around Mekelle. DVM thesis, Addis Aaba University, Faculty of veterinary medicine, Ethiopia.

Yirgalem, G., (1987). A survey on the prevalence and etiology of bovine mastitis in three state dairy farms around Addis Ababa, DVM thesis, Addis Ababa University, Faculty of veterinary medicine, Ethiopia. 